\title{
Erythropoietin in the Treatment of Cancer
}

\author{
Michael Henke \\ Klinik für Strahlenheilkunde, Universitätsklinikum, Freiburg i.Br., Germany
}

The glycoprotein erythropoietin is a key regulator of erythropoiesis. Transcription of the erythropoietin gene and release of erythropoietin protein into the blood stream are both induced by hypoxia. Upon binding to its cell-surface receptor, erythropoietin triggers a variety of cellular responses via several signaling pathways. Down-regulation of pro-apoptotic proteins (Fas-ligand, TRAIL, and BAD) and up-regulation and activation of anti-apoptotic proteins (Bcl-XL and $\mathrm{Bcl}-2)$ take place, leading to proliferation and differentiation of erythroid precursors. The result is an increase in red blood cell mass and in blood hemoglobin concentration. It is increasingly apparent that erythropoietin acts not only on hematopoietic tissue, but that many other tissue types express functional erythropoietin receptors as well. Further, erythropoietin receptors can be detected on various cancer cells (such as cancer of the breast, the female reproductive organs, the head and neck, stomach or kidneys, and on pediatric tumors), and in many cases those receptors have been shown to be functional, at least in vitro. Soon after recombinant human erythropoietin became readily available, it entered clinical practice and was used successfully for treatment of anemia associated with chronic renal failure. In the early 1990s the FDA granted approval for erythropoietin to treat chemotherapy-induced anemia in patients with non-myeloid malignancies. Unresolved concerns of a potential tumor stimulating capability directed a post-marketing study (N93-004) addressing the safety of the substance. The trial was terminated prematurely due to slow accrual rates; however, it was reassuring that it did not uncover serious safety issues.

Since that time, numerous phase I-IV studies have been performed. They focused on the efficacy of erythropoietin to increase hemoglobin levels and/or to improve quality of life of cancer patients. Quality of life, in particular, was felt to be improved. A broad acceptance of erythropoietin, especially in the US, was the consequence and erythropoietin became one of the best selling pharmaceutical drugs. The recognition of anemia as an independent predictive factor for cancer treatment and of anemia's role in the induction of tissue hypoxia another unfavorable condition - led to widespread preclinical and clinical research aimed at improving cancer treatment via the correction of anemia with erythropoietin. Although not specifically designed with this objective in mind, results from a large phase III trial suggested improved treatment outcome for cancer patients following efficient erythropoietin support [1].

However, two large recent trials, explicitly addressing the impact of erythropoietin on tumor control and/or survival, showed unexpected and significant negative results $[2,3]$. Thereafter several other randomized, controlled trials addressing the same objectives were terminated prematurely without providing conclusive data and a vivid discussion began that followed essentially three different lines of reasoning:

1. Clinical experience: The vast clinical experience with erythropoietin use in cancer patients does not suggest safety concerns.

2. Pathophysiology: Anemia promotes tumor tissue hypoxia, which impairs cancer treatment. Optimization of blood hemoglobin to physiologic concentrations should improve treatment outcome, and erythropoietin is an appropriate means of doing so.

3. Cellular biology: Erythropoietin can induce intracellular signaling in cancer cells that express appropriate receptors and resistance to subsequent cytotoxic treatment could result.

Even while acknowledging findings from cellular biology, most reports emphasize previous clinical experience and pathophysiology of anemia and call into question the results of the 'negative' erythropoietin trials. The article by Vaupel et al. [4] in this issue of ONKOLOGIE follows this reasoning and

\begin{tabular}{|c|c|c|}
\hline KARGER & (C) 2005 S. Karger GmbH, Freiburg & $\begin{array}{l}\text { PD Dr. med. Michael Henke } \\
\text { Klinik für Strahlenheilkunde }\end{array}$ \\
\hline $\begin{array}{l}\text { Fax +497614520714 } \\
\text { E-mail Information@Karger.de } \\
\text { www.karger.com }\end{array}$ & $\begin{array}{l}\text { Accessible online at: } \\
\text { www.karger.com/onk }\end{array}$ & $\begin{array}{l}\text { Universitätsklinikum } \\
\text { Robert-Koch-Strasse 4, } 79106 \text { Freiburg, Germany } \\
\text { Tel. +49 } 761 \text { 270-9559, Fax -9497 } \\
\text { E-Mail henke@uni-freiburg.de }\end{array}$ \\
\hline
\end{tabular}


specifically addresses the 'physiological' aspects of erythropoietin treatment. It was the Mainz group that very early, and continuously thereafter, viewed cancer prognosis from this perspective and focused predominantly on tumor hypoxia. The paper should be given, therefore, special credit.

Should this, however, resolve our doubts? The clinical data are conflicting: Comparing the recent 'negative' results from erythropoietin trials designed for tumor control and survival with trials addressing other objectives is of limited help. There is good reason to believe that adequate tumor oxygenation is essential for the successful outcome of radiation or of some cytostatic therapies and correction of the hypoxia-promoting anemia may make sense under these conditions. It is unlikely, however, that hypoxia impairs the quality of a surgical resection. Rather, hypoxia-induced cellular changes (such as the balance of pro- and anti-apoptotic proteins) allow cancer cells to escape treatment and anemia correction with erythropoietin will not improve - or may even worsen - this condition.
Contrarily, signaling imbalances are reported to enhance the efficacy of cytotoxic treatment in particular tumor models. In summary, it seems to become true, what had been suggested by one of the coauthors elsewhere, that to treat anemia in order to improve cancer cure and survival '... is probably more difficult and sophisticated than coping with symptoms of anemia...' [5].

How do we best deal with erythropoietin in clinical cancer medicine? Two 'negative' studies should not negate our enormous positive experience with erythropoietin in cancer patients that we have collected so far. However, they mandate for careful use of the substance. The current drug labeling and the ASCO/ASH- and EORTC-guidelines provide reasonable guidance. After all, clinical decision-making does not take place in the laboratory. It is built upon clinical data. Thus, concerns from controversial clinical observations require disproof or validation. Carefully designed and properly performed trials are the appropriate tools.

\section{References}

1 Littlewood TJ, Bajetta E, Nortier JW, Vercammen E, Rapoport B: Effects of epoetin alfa on hematologic parameters and quality of life in cancer patients receiving nonplatinum chemotherapy: Results of a randomized, double-blind, placebocontrolled trial. J Clin Oncol 2001;19:2865-2874.
Henke M, Laszig R, Rube C, Schafer U, Haase KD, Schilcher B, Mose S, Beer KT, Burger U, Dougherty $\mathrm{C}$, Frommhold H: Erythropoietin to treat head and neck cancer patients with anaemia undergoing radiotherapy: Randomised, double-blind, placebocontrolled trial. Lancet 2003;362:1255-1260.

3 Leyland-Jones B: Breast cancer trial with erythropoietin terminated unexpectedly. Lancet Oncol 2003;4:459-460.
4 Vaupel P, Dunst J, Engert A, Fandrey J, Feyer P, Freund M, Jelkmann W: Effects of recombinant human erythropoietin ( $\mathrm{rHuEPO}$ ) on tumor control in patients with cancer-induced anemia. Onkologie 2005;28: DOI: $10.1159 / 000084033$.

5 Dunst J: Management of anemia in patients undergoing curative radiotherapyerythropoietin, transfusions, or better nothing? Strahlenther Onkol 2004;180:671-681. 